Louisiana State University

LSU Digital Commons

Faculty Publications

Department of Biological Sciences

$5-1-2006$

\title{
Small-scale fuel variation alters fire intensity and shrub abundance in a pine savanna
}

Jarrod M. Thaxton

Louisiana State University

William J. Platt

Louisiana State University

Follow this and additional works at: https://digitalcommons.Isu.edu/biosci_pubs

\section{Recommended Citation}

Thaxton, J., \& Platt, W. (2006). Small-scale fuel variation alters fire intensity and shrub abundance in a pine savanna. Ecology, $87(5), 1331-1337$. https://doi.org/10.1890/

0012-9658(2006)87[1331:SFVAFI]2.0.C0;2

This Article is brought to you for free and open access by the Department of Biological Sciences at LSU Digital Commons. It has been accepted for inclusion in Faculty Publications by an authorized administrator of LSU Digital Commons. For more information, please contact ir@lsu.edu. 


\title{
SMALL-SCALE FUEL VARIATION ALTERS FIRE INTENSITY AND SHRUB ABUNDANCE IN A PINE SAVANNA
}

\author{
Jarrod M. Thaxton ${ }^{1}$ and William J. Platt \\ Department of Biological Sciences, Louisiana State University, Baton Rouge, Louisiana 70803 USA
}

\begin{abstract}
Small-scale variation in fire intensity and effects may be an important source of environmental heterogeneity in frequently burned plant communities. We hypothesized that variation in fire intensity resulting from local differences in fuel loads produces heterogeneity in pine savanna ground cover by altering shrub abundance. To test this hypothesis, we experimentally manipulated prefire fuel loads to mimic naturally occurring fuel-load heterogeneity associated with branch falls, needle fall near large pines, and animal disturbances in a frequently burned longleaf pine (Pinus palustris) savanna in Louisiana, USA. We applied one of four fuel treatments (unaltered control, fine-fuel removal, fine-fuel addition, wood addition) to each of $540\left(1-\mathrm{m}^{2}\right)$ quadrats prior to growing-season prescribed fires in each of two years (1999 and 2001). In both years fuel addition increased (and fuel removal decreased) fuel consumption and maximum fire temperatures relative to unaltered controls. Fuel addition, particularly wood, increased damage to shrubs, increased shrub mortality, and decreased resprout density relative to controls. We propose that local variation in fire intensity may contribute to maintenance of high species diversity in pine savannas by reducing shrub abundance and creating openings in an otherwise continuous ground cover.

Key words: environmental heterogeneity; fire intensity; fire temperature; fuel consumption; fuel load; ground cover; longleaf pine; Louisiana (USA); Pinus palustris; southeastern United States; vegetation gaps.
\end{abstract}

\section{INTRODUCTION}

Spatial variation in disturbance effects may generate environmental heterogeneity in many plant communities. Large-scale natural disturbances can vary locally in intensity, resulting in effects that are not spatially uniform (Turner et al. 1998). Within areas affected by a single disturbance event, effects on vegetation may range from minimal damage to complete mortality over a range of spatial scales. Nonuniform effects may produce a range of post-disturbance conditions (Platt and Connell 2003), e.g., areas with reduced competition from pre-disturbance survivors, which in turn may contribute to local patterns of diversity and community structure by providing recruitment opportunities for immigrating species.

Variation in fire intensity may be an important source of environmental heterogeneity in frequently burned communities. Natural fires occur frequently in ecosystems with a continuous ground cover of flammable herbaceous vegetation (e.g., temperate and tropical grasslands and savannas). Repeated "low-intensity fires"

Manuscript received 4 November 2005; revised 5 December 2005; accepted 8 November 2005. Corresponding Editor: J. S. Brewer.

${ }^{1}$ Present address: Institute of Pacific Islands Forestry, USDA Forest Service, 60 Nowelo Street, Hilo, Hawaii 96720 USA. E-mail: jthaxton@fs.fed.us typically occur before substantial accumulation of fuels (Andersen et al. 1998, Platt 1999, Ramos-Neto and Pivello 2000) and are "non-catastrophic" in that they tend to remove few individuals and no species (Platt and Connell 2003). For example, frequent fires top-kill ground-cover herbs and shrubs in pine savannas of the southeastern U.S., but these plants typically resprout from underground storage organs (e.g., Streng et al. 1993, Drewa et al. 2002). Small-scale differences in fire intensity may occur, however, even when fires are frequent (Williamson and Black 1981, Gibson et al. 1990). We hypothesize that this may result in reduction in size or removal of competitive dominants (e.g., large shrubs) where fires are locally intense. In this way, variation in fire intensity may introduce small-scale heterogeneity into the postfire environment of pine savanna ground cover.

Small-scale variation in fire intensity and effects may result from local variation in fuels. In frequently burned longleaf pine (Pinus palustris) savannas, canopy trees affect local fuel loads. Resin-filled needles are shed frequently (Landers 1991), resulting in accumulation of flammable fine fuels near large trees. Away from pines the needle densities are lower, and fine fuels are primarily herbaceous vegetation (Platt et al. 1991). Local variation in wood fuels is produced by downed trees and branches (Hermann 1993), especially after 
hurricanes (Platt and Rathbun 1993, Myers and van Lear 1998). Such spatial variation in fuels appears characteristic of all frequently burned pine savannas and may be an important determinant of fire intensity and fire effects in savanna ground cover.

We investigate the potential for small-scale differences in fire intensity, as produced by local variation in fuels, to damage shrubs, cause mortality, and alter density, thereby increasing postfire heterogeneity in the ground cover of frequently burned pine savanna. Prior to fires, we experimentally manipulated types and amounts of fuels in small areas and measured fuel loading. We measured maximum temperatures and fuel consumption during fires. After fires, we assessed damage, resprouting, and mortality of shrubs. We tested the following hypotheses: (1) Small-scale differences in types and amounts of fuels are predictably related to small-scale variations in fire intensity (i.e., at a scale experienced by individual plants). (2) Variation in fire intensity affects damage, resprouting, and mortality of ground-cover shrubs, producing local variation in postfire shrub environments.

\section{Methods \\ Study site and data collection}

We conducted this study in upland longleaf pine savanna at Camp Whispering Pines, Tangipahoa Parish, Louisiana, USA $\left(30^{\circ} 41^{\prime} \mathrm{N}\right.$; $90^{\circ} 29^{\prime} \mathrm{W}$, mean annual temperature $19^{\circ} \mathrm{C}$, mean annual rainfall $1626 \mathrm{~mm}$ ). The terrain is moderately dissected with elevation $25-50 \mathrm{~m}$ above mean sea level. Soils are well-drained Pleistoceneaged sands mixed with and capped by windblown loess. The canopy is dominated by longleaf pine that regenerated naturally following logging in the early 1900s (Noel et al. 1998). There is a diverse, relatively undisturbed ground cover of grasses, forbs, and shrubs. The site has been managed with biennial growing-season prescribed fires (April-May) since 1994.

In 1998 we randomly located five pairs of transects (20 $\times 80-100 \mathrm{~m}$ ) along gently sloping ravines (2-5\% slope). We divided each transect into two plots, high $(\mathrm{H})$ and low (L) elevation, at the elevation midpoint along the slope, resulting in a total of 20 plots of similar size. Within each plot, we randomly located $27\left(1-\mathrm{m}^{2}\right)$ quadrats, each containing at least one live ground-cover shrub stem $(<2 \mathrm{~cm} \mathrm{dbh})$ for a total of 540 quadrats in the study (Thaxton 2003). We defined "shrub" as any perennial, free-standing, woody plant (other than pines). In frequently burned savannas, most tree species have shrub-like growth forms. All shrub stems were counted and identified to species during an initial census in 1998. One year after each set of fires $(2000,2002)$, we counted number of shrub stems and recorded shrub mortality in all quadrats.

We manipulated fuel loads to mimic the range of observed natural fuel conditions in this savanna
(Appendix A). We randomly applied one of four fuel treatments (unaltered control, fine-fuel removal, finefuel addition, wood addition) to each $1-\mathrm{m}^{2}$ quadrat, plus a $30 \mathrm{~cm}$ buffer zone, immediately prior to prescribed fires in 1999 and 2001 (Thaxton 2003). Quadrats received the same fuel treatment in each year. Fuel addition simulated the input of pine needles or coarse woody debris by a tree fall or branch fall. We covered each fine-fuel-addition quadrat with $1.2 \mathrm{~kg}$ of longleaf pine needles arranged in a loosely piled continuous layer. For wood addition, we added $5 \mathrm{~kg}$ of pine wood pieces (each $\sim 1-2 \mathrm{~cm}$ diameter) across the existing fuel biomass. Fine-fuel removal created conditions expected in areas near animal burrows (Kaczor and Hartnett 1990) or away from large pines. From these quadrats, we removed $\sim 0.8 \mathrm{~kg}$ of pine needles and litter.

We sampled ground-cover fuel loads before and after fires. Prefire samples consisted of all aboveground biomass (both live and dead) from ground level to $1 \mathrm{~m}$ height, collected from a $400-900 \mathrm{~cm}^{2}$ area within the 30 $\mathrm{cm}$ treated buffer zone around each quadrat (Thaxton 2003). Samples were sorted into categories (standing woody, standing herbaceous, pine needles, other litter, dead wood 6-25 $\mathrm{mm}$ in diameter, and dead wood $>25$ $76 \mathrm{~mm}$ in diameter), oven dried at $50^{\circ} \mathrm{C}$, and weighed. We collected postfire fuel samples adjacent to prefire fuel samples. Postfire fuel samples were separated into finefuel and wood categories, oven dried at $50^{\circ} \mathrm{C}$ and weighed. Fuel consumption was estimated as the difference between pre- and postfire fuel samples.

The fuel loads produced by treatments approximated the observed natural fuel variation (Appendix A). Total fuel loads (values given as mean \pm SE) in unaltered controls averaged $1.01 \pm 0.09 \mathrm{~kg} / \mathrm{m}^{2}$ in 1999 fires and $0.97 \pm 0.08 \mathrm{~kg} / \mathrm{m}^{2}$ in 2001 fires, with a range over both years from 0.21 to $5.9 \mathrm{~kg} / \mathrm{m}^{2}$. In both years, fine-fuel removal resulted in fuel loads near the minimum observed in unaltered controls $\left(0.2 \pm 0.02 \mathrm{~kg} / \mathrm{m}^{2}\right)$, while fine-fuel addition generated fuel loads more than twice that of unaltered controls $\left(2.19 \pm 0.04 \mathrm{~kg} / \mathrm{m}^{2}\right)$. Finally, wood addition produced fuel loads of $6 \pm 0.09 \mathrm{~kg} / \mathrm{m}^{2}$, similar to the maximum observed in unaltered controls.

We burned all transects with prescribed head or flanking fires during the early growing season (late April) in 1999 and 2001 (see Plate 1). Fires were ignited from 1 to 12 days following the last measurable rainfall (Appendix B). We estimated maximum temperatures using methods of Drewa et al. (2002). We used a set of 15 Tempil pellets (Big Three Industries, Tempil Division, South Plainfield, New Jersey, USA) spanning a range of melting temperatures from $48^{\circ}$ to $1371^{\circ} \mathrm{C}$ (Thaxton 2003). A set of pellets, each wrapped in aluminum foil, was placed at ground level in each quadrat before fires, retrieved after fires, and scored for melting. Melting temperatures were corrected for wrapping in aluminum foil using the regression equation of 
Drewa et al. (2002). Adjusted melting temperatures ranged from $85^{\circ}$ to $1553^{\circ} \mathrm{C}$ (Thaxton 2003).

We recorded damage to shrubs immediately after each fire. We categorized each $1-\mathrm{m}^{2}$ quadrat as either "damage" or "no damage" based on presence of visible damage. Damage categorizations were made independently for leaf and stem damage in each quadrat. "Visible damage" was defined as $>10 \%$ of prefire leaves or stems consumed during fire. Within damage quadrats, a second categorization was made to provide an estimate of the severity of visible damage. Quadrats containing shrubs with $>90 \%$ consumption of either leaves or stems sustained "complete" damage, while quadrats with consumption of $<90 \%$ sustained "partial" damage.

\section{Statistical analyses}

The experimental design was a repeated-measures split plot within blocks. Fuel consumption, maximum fire temperature, shrub damage, number of shrub resprouts, and shrub mortality were measured in quadrats receiving fuel treatments (split plots) in each of two years (split split plots). Quadrats (subplots) were nested within plots (whole plots) located at low or high elevation. Whole plots were nested within transects (subblocks) within ravines (blocks). Linear mixed models were constructed with fuel, elevation, and year as fixed effects and quadrats, transects, and ravines as random effects. Analyses used maximum-likelihood techniques incorporating covariance parameters associated with random effects into tests of significance for fixed effects (Thaxton 2003).

For all analyses, we constructed orthogonal linear contrasts to test a priori null hypotheses regarding fuelload main effects and fuel $\times$ year interaction effects. Linear contrasts for fuel tested the following null hypotheses: (1) added fuel quadrats (fine-fuel addition + wood addition) did not differ from quadrats without added fuels (unaltered controls + fine-fuel removals), (2) fine-fuel addition did not differ from wood addition and (3) unaltered controls did not differ from fine-fuel removals. Linear contrasts for fuel $\times$ year effects tested the following null hypotheses: (1) added fuel quadrats did not differ from quadrats without added fuels one year following the first fire and one year following the second fire, (2) fine-fuel addition did not differ from wood addition one year after the first fire and one year after the second fire, and (3) unaltered controls did not differ from fine-fuel removals one year after the first fire and one year after the second fire.

We analyzed treatment effects on fuel consumption and fire temperature using ANOVA and number of resprouts using ANCOVA. Analyses were conducted using PROC MIXED in SAS (SAS Institute 1997) with $\alpha=0.05$. Resprout density was natural-log transformed $(n+1)$ to meet model assumptions. Initial stem density from the pretreatment census (1998) was used as a covariate. Replication of fuel treatments was unbalanced, so a Satterthwaite approximation was used to calculate appropriate denominator degrees of freedom for $F$ tests.

Treatment effects on shrub mortality and damage to leaves and stems were analyzed with generalized linear mixed models. Models were generated by invoking PROC MIXED within the GLIMMIX macro (Littell et al. 1996). Models were specified to contain a logit link and a binomial error distribution. We separately fit two models to both leaf-damage and stem-damage data. First, probability of visible damage was determined based on data from all quadrats. "Damage" was considered as success $(=1)$ and "no damage" as failure $(=0)$. Second, the probability of complete damage was analyzed in quadrats where visible damage occurred. "Complete damage" was success $(=1)$ and "partial damage" was failure $(=0)$. Because two analyses were run on the same data a Bonferroni correction $(\alpha=0.05 / 2$ $=0.025$ ) was used in analyses. All models converged to analytical solutions in $<20$ iterations.

\section{RESULTS}

Fuel treatments produced large differences in fuel consumption and maximum fire temperature (Fig. 1, Appendix C). During fires in both years, fuel addition (of either fine fuel or wood) increased consumption by $>100 \%$ and mean maximum temperature by $300-400^{\circ} \mathrm{C}$ above that of unaltered control. Conversely, fuel removal reduced consumption by an order of magnitude and maximum temperature by $>400^{\circ} \mathrm{C}$ below that of unaltered control. Furthermore, wood addition tended to increase consumption and maximum temperature above that of fine-fuel addition, particularly during fires in 1999. All fuel main effects and linear contrasts were highly significant $(P<0.001)$. A decrease in consumption and maximum temperature in the wood addition treatment during 2001 fires resulted in significant fuel $\times$ year interactions $(P<0.001$ for both variables). Linear contrasts for the interaction of fuel $\times$ year indicated that the difference between wood addition and fine-fuel addition treatments was significantly greater during the first set of fires (1999, $P<0.001$ for both variables). Finally, a $22 \%$ decrease in overall fuel consumption during 2001 fires resulted in a significant year effect $(P<$ 0.001). Maximum temperature did not differ between years $(P=0.24)$.

By altering fire intensity, fuel treatments affected patterns of damage to shrubs during fires. Stem damage was highest in fuel addition treatments, intermediate in unaltered control, and lowest in fuel removal (Fig. 2A, Appendix D). The overall effect of fuel was highly significant for both visible and complete stem damage $(P$ $<0.001$, Appendix D). Linear contrasts indicated that significant differences occurred between quadrats with fuels added and quadrats with fuel removed (Appendix 

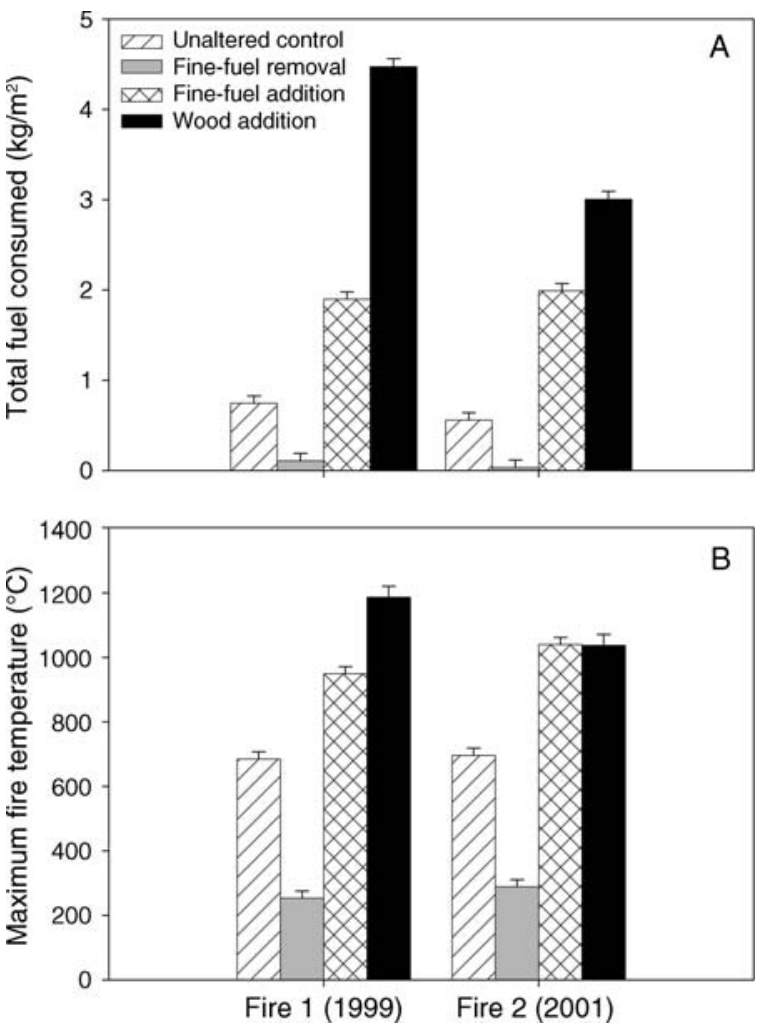

FIG. 1. Effects of fuel treatments on aspects of fire behavior: (A) fuel mass consumed (least-squares means $+\mathrm{SE}$ ) and (B) maximum fire temperature (least-squares means $+\mathrm{SE}$ ) at ground level during fires in 1999 and 2001.

D). In particular, fuel addition increased the probability of complete damage relative to unaltered fuels (Fig. 2A). Some aspects of damage were less frequent in the second year of fires. The probability of visible stem damage was 0.74 in 1999 and decreased to 0.61 in 2001. This difference was significant $(P<0.001)$. Complete stem damage was also affected by year, but not in a consistent manner across fuel-load treatments. The completedamage probability for unaltered control and pineneedle addition increased, while the probability for wood addition and fuel removal decreased. This resulted in a significant year $\times$ fuel interaction $(P=0.005)$.

Fuel treatments affected postfire shrub stem densities (Fig. 2B). In the initial 1998 census, we counted 6348 stems of 32 shrub species (Appendix E). In each year, $>99 \%$ of stems were top-killed during fires. At least some stems of all species resprouted. After adjusting for initial prefire $(1998)$ density $(P<0.001$ for covariate), fuel treatments significantly affected shrub density $(P<$ 0.001, Appendix F). Across both years, quadrats that received fuel addition (either fine fuel or wood) contained on average $30 \%$ fewer postfire stems than quadrats with fine fuels removed or unaltered $(P<0.001$ for linear contrasts). Furthermore, wood-addition quad-
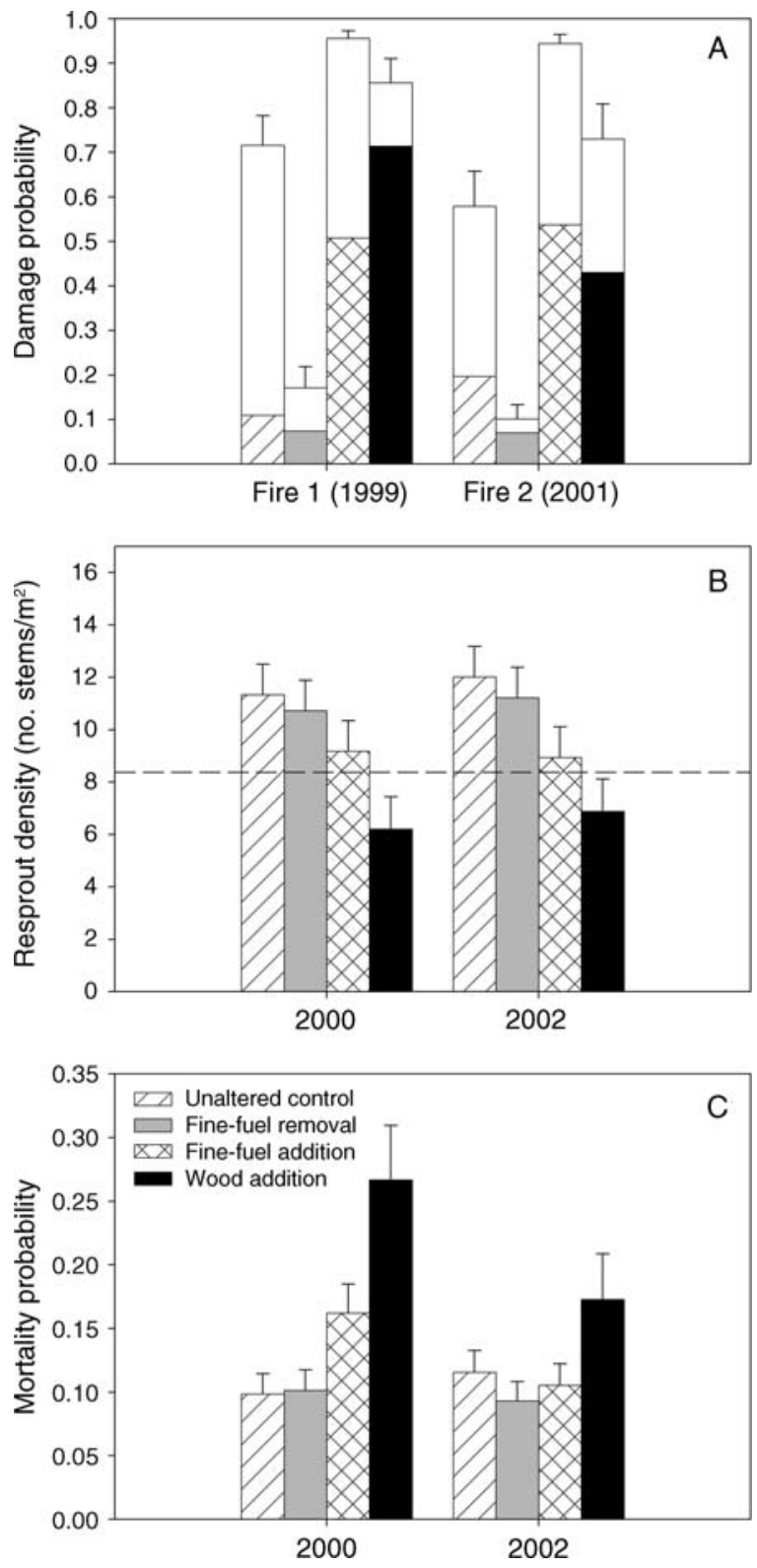

FIG. 2. Effects of fuel treatments on ground-cover shrubs. (A) Probability of damage to shrub stems during fires in 1999 and 2001. Overall bar height indicates the mean probability of visible damage ( $>10 \%$ consumed). The smaller bars (shaded or patterned) indicate probability that observed damage was complete ( $>90 \%$ consumed). Values are least-squares means and SE, back-transformed from logits. (B) Shrub ramet density (least-squares means and SE) one year following fires (2000, 2002). The dashed horizontal line indicates overall mean pretreatment density (1998). (C) Probability of shrub mortality (least-squares means + SE, back-transformed from logits) one year following fires $(2000,2002)$.

rats contained on average $28 \%$ fewer stems than pineneedle-addition quadrats $(P<0.001)$. Stem density did not differ significantly between fine-fuel removal and 


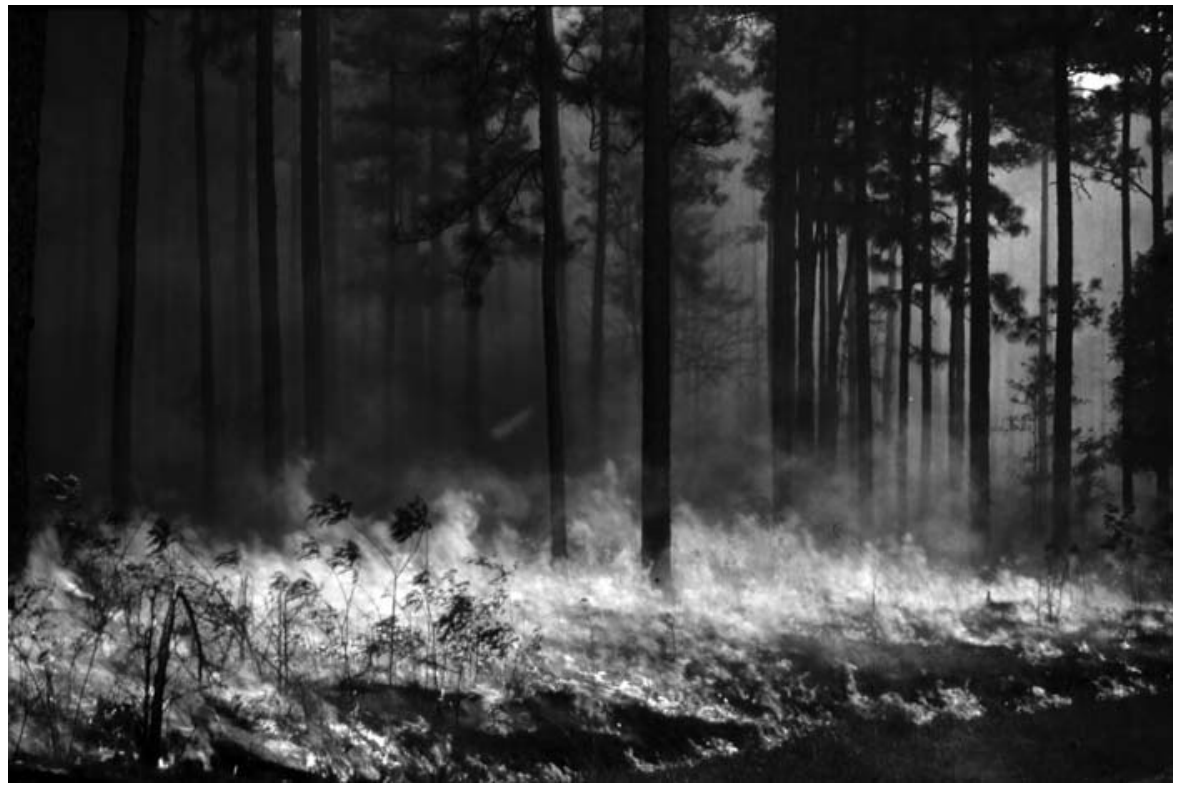

Plate 1. Prescribed fire in upland longleaf pine (Pinus palustris) savanna at Camp Whispering Pines, Louisiana, USA. Photo credit: Virginia Thaxton.

unaltered control. Overall stem density was $8 \%$ higher following the second fires (2002) resulting in a year effect that approached significance $(P=0.05)$.

Fuel treatments also affected shrub mortality (Fig. 2C, Appendix F), resulting in a significant main effect of fuel $(P<0.001)$. The addition of fuels (either fine fuels or wood) increased the probability of mortality, by as much as $150 \%$, above that of unaltered controls and fuel removals (linear contrast $P<0.001$ ). Furthermore, the addition of wood increased the probability of mortality above that of fine-fuel addition. Overall mortality was greater after fires in 1999 (16\%) than in 2001 (12\%) resulting in a significant year effect $(P=0.015)$. Similarly, the relative effect of overall fuel addition (fine fuel plus wood) was significantly less in 2001 than 1999 (linear contrast for fuel $\times$ year interaction $P=0.03$ ).

\section{DISCUSSION}

Small-scale variation in types and amounts of fuels increased the range of fire intensity and fire effects in the ground cover of this frequently burned pine savanna. Variation in fuels at a scale as small as $1 \mathrm{~m}^{2}$ and within the range of naturally occurring fuel densities produced substantial differences (as much as an order of magnitude) in local fire intensity (as indicated by fuel consumption and maximum fire temperature). This variation in fire intensity produced short-term damage and resulting effects on shrub abundance that persisted at least one year. As a result, postfire environmental heterogeneity was increased within the ground-cover community. Experimental fuel manipulation has also been shown to alter fire intensity, damage shrubs and trees, and affect resprouting in other community types: chaparral (Moreno and Oechel 1993), tropical dry forest (Kennard et al. 2002), palmetto-dominated flatwoods (Hierro and Menges 2002), and desert grasslands (Drewa 2003). Small-scale variation in fire intensity and effects as a result of local fuel conditions may be characteristic of fire-frequented ecosystems.

Variation in fire intensity produces environmental heterogeneity within pine savanna ground cover. Postfire shrub environments range from local "hotspots," where high fire intensity results in shrub mortality and reduced stem density (ground-cover gaps), to areas where fuel consumption and shrub damage are minimal. High fire intensity thus may provide sites where competition is reduced, increasing recruitment opportunities for a range of species by creating openings devoid of shrubs in an otherwise-continuous ground-cover community. Most fire-generated openings are small (at the scale of individual stems or plants) and are likely to be closed by adjacent resprouting vegetation. Plants at gap edges may experience increased growth and flowering relative to plants within intact ground cover (Brewer et al. 1996). Larger openings that persist over time should provide postfire establishment opportunities and transient refuges for colonists, especially seed bank species (Platt et al. 2006). In particular, ground-cover gaps of this type may provide some of the rare opportunities for seedling establishment in the continuous ground cover of frequently burned pine savannas (Streng et al. 1993). In contrast, areas of low fire intensity may facilitate the development of dense shrub patches where herbaceous species are largely excluded (Schmitz et al. 2002, Slocum 
et al. 2003). We propose that the presence of a variety of postfire conditions produced by variable fire intensity may contribute to species coexistence within pine savanna ground cover.

Small-scale variation in fire intensity may interact with local environmental conditions to increase the range of postfire environments produced over time and space. For example, prefire weather conditions affect fuel moisture, which in turn could contribute to differences in fire effects among years. In our study, fire intensity and effects on shrubs tended to be greater in 1999 fires than 2001 fires, coinciding with prefire rainfree intervals in 1999 that were twice those of 2001 (Appendix B). Although fires in both years produced a range of fire intensity and effects on shrubs, shrub mortality was substantially higher in 1999. Similarly, spatial variation in soil moisture within the area burned by a single fire could increase variation in effects as fires move across ground-cover community types (Walker and Peet 1983, Peet and Allard 1993, Drewa et al. 2002). In this way, both transient and persistent environmental conditions could contribute to the range of postfire microhabitats produced by fires of variable intensity.

Variation in fire intensity may be an important driver of high species diversity in pine savannas. Large shrubs reduce local herbaceous diversity within savanna ground cover (Schmitz et al. 2002). Consequently, frequent fires that maintain shrubs at small stature have been suggested to maintain high diversity in these communities (Glitzenstein et al. 2003). We propose that variation in fire intensity may also contribute to high local diversity by increasing the range of postfire conditions produced by frequent fires. Evidence from other frequently burned communities indicates that a number of species in pine savannas may be able to take advantage of areas of reduced shrub dominance or ground-cover gaps. For example, nearly one third of common species and $85 \%$ of uncommon species in scrubby Florida flatwoods depend on gaps generated during fires (Menges and Hawkes 1998, Young and Menges 1999). Furthermore, spatial variation in fire intensity may be an important selection pressure in pine savannas, promoting partitioning of gap and non-gap areas by gap specialists and species that use adaptive plasticity to tolerate competition (Gowe and Brewer 2005). In this way frequent fires may interact with local variation in fire intensity to repeatedly generate postfire conditions that promote species coexistence at small spatial scales in pine savannas.

\section{ACKNOWLEDGMENTS}

We are grateful to Jean Fahr and the Southeast Louisiana Girl Scout council for providing logistical support and site access. Special thanks to Larry Ehrlich and the CWP staff for conducting prescribed fires. We are particularly indebted to Virginia Thaxton for help with field work. Chris Thibodaux and other LSU undergraduates assisted in the field and laboratory. Thanks to David Blouin for advice on statistical analyses. Helpful comments on previous drafts were provided by Steve Brewer, Julie Denslow, Kyle Harms, Michael Stine,
James Cronin, Kyle Haines, Heather Passmore, Satya Maliakal, and two anonymous reviewers. Funding for this study was provided by grants from Sigma Xi (J. M. Thaxton) and the TNC Ecosystem Research Program (J. M. Thaxton and W. J. Platt, principal investigators).

\section{Literature Cited}

Andersen, A. N., R. W. Braithwaite, G. D. Cook, L. K. Corbett, R. J. Williams, M. M. Douglas, A. M. Gill, S. A. Setterfield, and W. J. Muller. 1998. Fire research for conservation management in tropical savannas: introducing the Kapalga fire experiment. Australian Journal of Ecology 23:95-110.

Brewer, J. S., W. J. Platt, J. S. Glitzenstein, and D. R. Streng. 1996. Effects of fire-generated gaps on growth and reproduction of golden aster (Pityopsis graminifolia). Bulletin of the Torrey Botanical Club 123:295-303.

Drewa, P. B. 2003. Effects of fire season and intensity on Prosopis glandulosa Torr. var. glandulosa. International Journal of Wildland Fire 12:1-11.

Drewa, P. B., W. J. Platt, and E. B. Moser. 2002. Fire effects on resprouting of shrubs in headwaters of southeastern longleaf pine savannas. Ecology 83:755-767.

Gibson, D. J., D. C. Hartnett, and G. L. S. Merrill. 1990. Fire temperature heterogeneity in contrasting fire prone habitats: Kansas tallgrass prairie and Florida sandhill. Bulletin of the Torrey Botanical Club 117:349-356.

Glitzenstein, J. S., D. R. Streng, and D. D. Wade. 2003. Fire frequency effects on longleaf pine (Pinus palustris P. Miller) vegetation in South Carolina and northeast Florida, USA. Natural Areas Journal 23:22-37.

Gowe, A. K., and J. S. Brewer. 2005. The evolution of firedependent flowering in goldenasters (Pityopsis spp.). Journal of the Torrey Botanical Society 132:384-400.

Hermann, S. M. 1993. Small-scale disturbances in longleaf pine forests. Proceedings of the Tall Timbers Fire Ecology Conference 18:265-274.

Hierro, J. L., and E. S. Menges. 2002. Fire intensity and shrub regeneration in palmetto-dominated flatwoods of central Florida. Florida Scientist 65:51-61.

Kaczor, S. A., and D. C. Hartnett. 1990. Gopher tortoise (Gopherus polyphemus) effects on soils and vegetation in a Florida sandhill community. American Midland Naturalist 123:100-111.

Kennard, D. K., K. Gould, F. E. Putz, T. S. Fredericksen, and F. Morales. 2002. Effect of disturbance intensity on regeneration mechanisms in a tropical dry forest. Forest Ecology and Management 162:197-208.

Landers, J. L. 1991. Disturbance influences on pine traits in the southeastern United States. Proceedings of the Tall Timbers Fire Ecology Conference 17:61-95.

Littell, R. C., G. A. Milliken, W. W. Stroup, and R. D. Wolfinger. 1996. SAS system for mixed models. SAS Institute, Cary, North Carolina, USA.

Menges, E. S., and C. V. Hawkes. 1998. Interactive effects of fire and microhabitat on plants of Florida scrub. Ecological Applications 8:935-946.

Moreno, J. M., and W. C. Oechel. 1993. Demography of Adenostoma fasciculatum after fires of different intensities in southern California chaparral. Oecologia 96:95-101.

Myers, R. K., and D. H. van Lear. 1998. Hurricane-fire interactions in coastal forests of the south: a review and hypothesis. Forest Ecology and Management 103:265-276.

Noel, J. M., W. J. Platt, and E. B. Moser. 1998. Structural characteristics of old- and second-growth stands of longleaf pine (Pinus palustris) in the Gulf Coastal region of the USA Conservation Biology 12:533-548.

Peet, R. K., and D. J. Allard. 1993. Longleaf pine vegetation of the southern Atlantic and eastern Gulf Coast regions: a preliminary classification. Proceedings of the Tall Timbers Fire Ecology Conference 18:45-81. 
Platt, W. J. 1999. Southeastern pine savannas. Pages 23-51 in R. C. Anderson, J. S. Fralish, and J. M. Baskin, editors. Savannas, barrens, and rock outcrop communities of North America. Cambridge University Press, Cambridge, UK.

Platt, W. J., S. M. Carr, M. Reilly, and J. Fahr. 2006. Pine savanna overstory influences groundcover biodiversity. Applied Vegetation Science 9:37-50.

Platt, W. J., and J. H. Connell. 2003. Natural disturbances and directional replacement of species. Ecological Monographs 73:507-522.

Platt, W. J., J. S. Glitzenstein, and D. R. Streng. 1991. Evaluating pyrogenicity and its effects on vegetation in longleaf pine savannas. Proceedings of the Tall Timbers Fire Ecology Conference 17:143-161.

Platt, W. J., and S. L. Rathbun. 1993. Dynamics of an oldgrowth longleaf pine population. Proceedings of the Tall Timbers Fire Ecology Conference 18:275-297.

Ramos-Neto, M. B., and V. R. Pivello. 2000. Lightning fires in a Brazilian savanna National Park: rethinking management strategies. Environmental Management 26:675-684.

SAS Institute. 1997. SAS/STAT Software: changes and enhancements through Release 6.12. SAS Institute, Cary, North Carolina, USA.

Schmitz, M., W. Platt, and J. DeCoster. 2002. Substrate heterogeneity and number of plant species in Everglades savannas (Florida, USA). Plant Ecology 160:137-148.
Slocum, M. G., W. J. Platt, and H. C. Cooley. 2003. Effects of differences in prescribed fire regimes on patchiness and intensity of fires in subtropical savannas of Everglades National Park, Florida. Restoration Ecology 11::91-102.

Streng, D. R., J. S. Glitzenstein, and W. J. Platt. 1993. Evaluating effects of season of burn in longleaf pine forests: a critical literature review and some results from an ongoing long-term study. Proceedings of the Tall Timbers Fire Ecology Conference 18:227-263.

Thaxton, J. M. 2003. Effects of fire intensity on groundcover shrubs in a frequently burned longleaf pine savanna. Dissertation. Louisiana State University, Baton Rouge, Louisiana, USA.

Turner, M. G., W. L. Baker, C. J. Peterson, and R. K. Peet. 1998. Factors influencing succession: lessons from large, infrequent, natural disturbances. Ecosystems 1:511-523.

Walker, J., and R. K. Peet. 1983. Composition and species diversity of pine-wiregrass savannas of the Green Swamp, North Carolina. Vegetatio 55:163-179.

Williamson, G. B., and E. M. Black. 1981. High temperature of forest fires under pines as a selective advantage over oaks. Nature 293:643-644.

Young, C. C., and E. S. Menges. 1999. Postfire gap-phase regeneration in scrubby flatwoods on the Lake Wales Ridge. Florida Scientist 62:1-12.

\section{APPENDIX A}

One figure and one table illustrating natural fuel-load variation in longleaf pine savanna at Camp Whispering Pines in southeastern Louisiana, USA (Ecological Archives E087-078-A1).

\section{APPENDIX B}

A table with rainfall data for the period prior to fires in 1999 and 2001 at Camp Whispering Pines, Louisiana, USA (Ecological Archives E087-078-A2).

\section{APPENDIX C}

One table of fire-behavior data and two ANOVA tables for fuel consumption and maximum fire temperature (Ecological Archives E087-078-A3).

\section{APPENDIX D}

One figure and four ANOVA tables for damage to shrub leaves and stems during fires (Ecological Archives E087-078-A4).

\section{APPENDIX E}

A table of initial prefire (1998) shrub densities within $540\left(1-\mathrm{m}^{2}\right)$ sample quadrats at Camp Whispering Pines, Louisiana, USA (Ecological Archives E087-078-A5).

\section{APPENDIX F}

ANCOVA table for stem density and ANOVA table for mortality (Ecological Archives E087-078-A6). 